\title{
Building limes in the United Kingdom
}

Paul Livesey

Consultant, Paul Livesey Consultancy, Clitheroe, UK

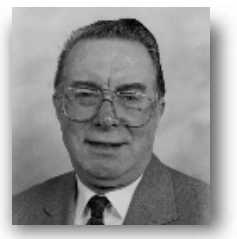

This paper traces the development of lime as a building material, from ancient times to classical Roman technology, its loss in the Dark Ages, its restoration in the technical revolution until superseded by cement and its re-emergence in recent times. It follows the developing product with evolving production technology and its classification with increased understanding of materials science. The modern understanding of microstructure is used to explain the benefits of porosity and plasticity, and examples are given of mixes for exposure conditions. The environmental benefits are compared with those of alternative binders.

\section{Introduction}

Lime, in its basic form of calcium oxide, is fundamental to the whole of the UK building industry. It is the major ingredient in hydrated calcium lime and natural hydraulic limes, and is a production intermediate in the whole spectrum of cements from prompt cement to Portland cements and calcium aluminate cements (Taylor, 1997). It is an essential ingredient in the production of iron and steel, being used to extract impurities during the fusion process to form slag, the granulated form being a major constituent of composite cements. One might even claim that iron is a by-product of its manufacture. Even the current vogue for the use of glass as a structural building component is not immune: lime is an essential ingredient for the refining of glass properties. This paper considers that part of the lime-cement spectrum occupied by the pure limes (termed 'air limes') and natural hydraulic limes.

When the subject of lime is raised, the immediate and common thought is ancient or even pre-historic construction. This is unsurprising since lime production is believed to have developed in the Middle East around 10000 years ago (Cowper, 1927); recent archaeological excavations in western China (CASS, 2009) suggest similar or even earlier evidence. The technology was developed and further refined by the ancient Greeks, with the advantages of matured putty and finely ground lime being extolled by Pliny the Younger. It was, however, the Romans, particularly Director of Ordnance, Vitruvius, to whom we owe the most developed and authoritative writings (Vitruvius, 1880 (trans.)). A major innovation at this time was the introduction of hydraulic constituents such as volcanic ash, pozzolana and crushed tile or brick ceramic to the lime to improve strength and particularly resistance to marine environments. Subsequently, in the Dark Ages much of this skill was lost, preserved only by a small number of religious builders.
The development of classical learning in Renaissance times led to the rediscovery of the arts of plaster and incorporation of gypsum that were to result in the major palaces that survive today. The principle of Vitruvius - that the best mortar was to be produced from the purest of lime, gauged by its whiteness, combined with hydraulic constituents - persisted until the mid-eighteenth century. Despite this, masons in the south of England had observed from experience that limes made from the grey chalk beds had superior strength to white limes, albeit the term 'semihydraulic' was unknown at that time (Holmes, 2006). The scientific basis for hydraulicity was established by two eminent workers of the time. John Smeaton carried out a review of English limes produced from a variety of sources of limestones and chalks, and found that the necessary quick setting and strong characteristics he needed for the reconstruction of the Eddystone lighthouse (Smeaton, 1791) came from those with a proportion of insoluble (in acid) clay, particularly from the Blue Lias limestones in the viscinity of Aberthaw. Not content with this discovery, Smeaton also applied the Roman technique of adding volcanic pozzolana to his mortars. Subsequent to this, the French civil engineer Vicat researched the limestones and chalks of France (Vicat, 1837), refining Smeaton's findings and arriving at a series of classifications for hydraulicity - feebly, moderate and eminently - that exists to the present day. As production techniques improved throughout the following century, lime and clay began to be heated to higher temperatures to increase hydraulicity, eventually reaching fusion and the formation of hard 'clinker' at which point they became known as 'cements'. From this time, their use overtook that of even hydraulic limes so that by the early twentieth century, limes had almost disappeared from normal construction and, by the mid-century, from building codes of practice (except as mortar plasticisers).

\section{Lime production}

The chemical process involved in lime burning basically consists of the dissociation by heat of calcium (or magnesium) 
carbonates. Magnesium limes are not normally encountered in the UK, so this paper concentrates on calcium limes. Sources of calcium carbonate are the various forms of limestone rock, including chalk. Other rarer sources include oyster and other shells and even, potentially, egg shells (Edwards, 2009). Application of heat causes dissociation of calcium carbonate, releasing gaseous carbon dioxide and leaving calcium oxide (quicklime), which is then cooled in ambient air to limit recarbonation. These high-purity limes are known as air limes.

Where the source limestone contains finely dispersed argillaceous (clayey) or siliceous material, generally referred to as the 'clay' constituent, the resulting lime contains activated silicates and is referred to as 'natural hydraulic lime'. Other 'hydraulic' limes are produced by mixing Portland cement with air limes, but these are not covered in this paper. During burning, as the temperature rises, quicklime released from the calcium carbonate reacts with the clay constituents, mainly silica, to form dicalcium silicate, also known as belite. A schematic representation of the reactions is shown in Figure 1. This is, of course, a simplification of a complex series of reactions, many of which occur in the solid phase and are dependent on highly localised microclimates. For instance, a kiln operating temperature of $950^{\circ} \mathrm{C}$ would, theoretically, avoid formation of any tricalcium silicate (alite); in fact, there is always a trace formed in localised hot spots in the kiln. Similarly, depending on stone size and local carbon dioxide concentrations, not all of the stone is automatically calcined at this optimum temperature.

In its simplest form, the lime 'kiln' consisted of alternate layers of broken limestone and fuel, mainly wood, built into a pile (Wingate, 1985). Sometimes, to concentrate the heat, the base

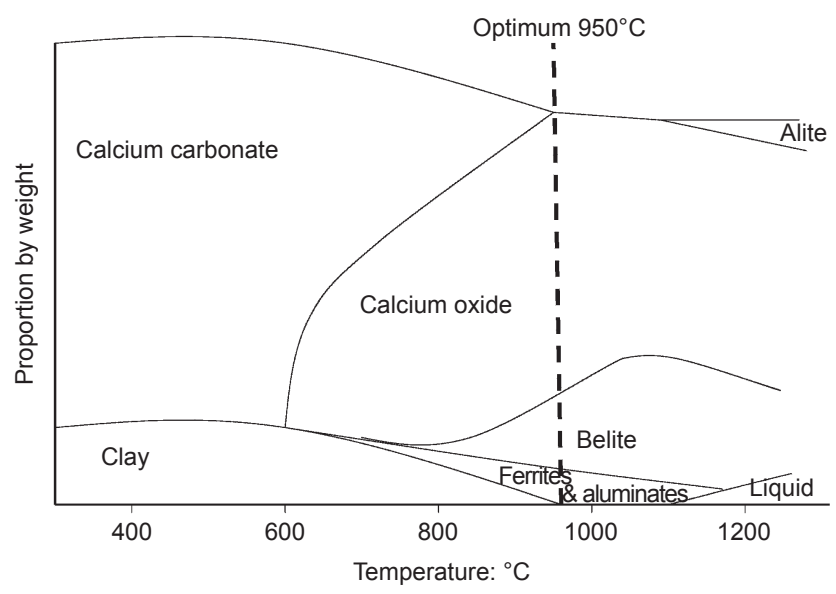

Figure 1. Phase changes during the calcination of natural hydraulic lime constituents was dug down into a depression and the whole covered by a layer of clay. It was necessary to be able to provide air for combustion and this was achieved by leaving opening vents around the base of the clay or digging trenches to the sides of the pit. These developed into the various stages of shaft kilns, the remains of which are commonly seen in the UK countryside. Initially stone built into the side of a quarry, limestone and fuel were fed into the top and the resulting lime was drawn from the base. The more sophisticated of these developed into continuous feed and draw units, often in multiple banks as shown in Figure 2, which shows the lime works at Charlestown, Scotland. This was one of the largest production units in existence in the early nineteenth century, producing $90000 \mathrm{t} /$ year.

Key factors in control of the kiln and the resultant lime quality were: selection and size of the stone feed; quality, quantity and dispersion of fuel; and control of air to ensure complete combustion over the entire kiln. The size of stone feed affects the reaction time and flow of air through the kiln; a smaller size presents more surface area to react with the hot gas but, if too small, leaves little space for the gas to pass through, thus blocking the release of carbon dioxide and choking the burn. The temperature of the burn is controlled by the relative amounts of fuel and air. If the temperature is too low, or the burn is not allowed to continue to completion, unburnt stone will result. The most reactive lime is obtained from a slow burn at a relatively low temperature of around $900-950^{\circ} \mathrm{C}$. As the clay content of the feed increases, extra time and a higher temperature are required to allow the quicklime formed to react with the silica in the clay. Burning at too high a

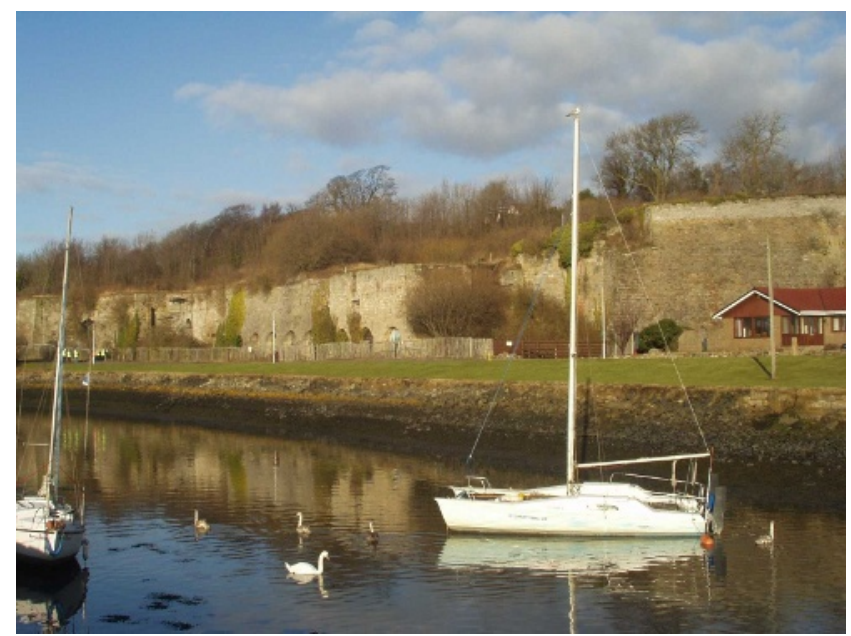

Figure 2. Shaft kilns at Charlestown, Fife (photograph permission of the Scottish Lime Centre Trust) 
temperature will result in a more dense form of quicklime that is less reactive and, in the extreme, is inert.

As kiln technology developed, higher temperatures were able to be achieved and emphasis shifted to the production of increasingly hydraulic cements. In the residual lime industry, kiln technology proceeded at a slower rate, learning from cement technology but without the commercial incentive of volumes and hence investment. In the later part of the twentieth century, interest in lime (particularly natural hydraulic lime) increased, so that customised technology began to be applied to development of lime kilns. The modern lime kiln is now characterised by a complex gas-fired shaft kiln (Figure 3) capable of close control of temperature and hence quality and fuel efficiency.

The final stage in lime production (little is sold as quicklime and only then to specialist users) is the slaking process. Quicklime is unstable, reacting with moisture in the air, and therefore requires careful storage to prevent deterioration. The addition of water to quicklime releases large amounts of heat that can cause the water to boil, thus necessitating careful control and protective equipment. Lime used for most building purposes is the hydrated form, that is, it has undergone a slaking process whereby water is added in controlled amounts. In the case of air limes where the water addition is just sufficient to hydrate the calcium oxide quicklime content to dry powder calcium hydroxide, the product is referred to as hydrated lime.

Use of an excess of water in the slaking process, accompanied by good agitation, produces a milky suspension of calcium hydroxide. In time, the solids in this 'milk of lime' settle and, if excess water is drained off, the product is lime putty. Storage for longer periods causes the calcium hydroxide particles to repeatedly dissolve and recrystallise to finer and finer crystallites, producing matured lime putty. Lime putty can be produced from hydrated lime but then needs a long period of maturation to approach the quality of putty produced from milk of lime. Lime putty needs to be stored with sufficient water to cover the surface to prevent carbonation.

Slaking of the free calcium oxide in hydraulic lime is necessary to avoid reaction of the unstable quicklime in subsequent work. This requires careful control to ensure full hydration without hydrating and reducing the reactivity of the hydraulic constituents; it is often carried out in association with grinding the hydraulic lime to produce dry powdered natural hydraulic lime.

\section{Classification of building limes}

Building limes are, in most cases, not mixed products. Depending on type, they harden by absorbing carbon dioxide from the air and/or by combining with water hydraulically. On

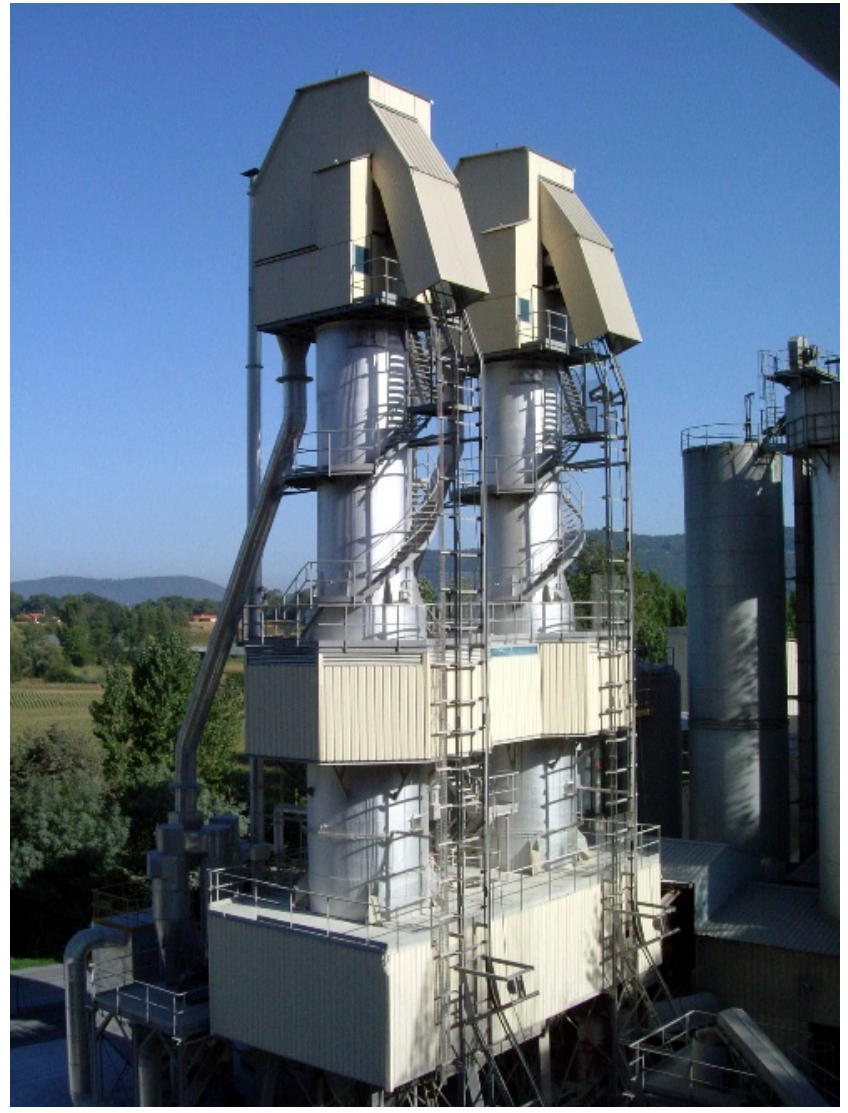

Figure 3. The compact nature of a modern lime kiln (photograph permission of SOCLI Limes, France)

mixing with water, building limes form a paste that improves the workability (flow and penetration) and water retention of mortars in the plastic state. During the life of lime-based mortars, carbonation occurs and this results in the filling of small cracks and voids. This increases compressive, flexural and bond strength and reduces rain penetration. This beneficial process, which enhances durability, is known as autogenous healing. For these reasons, the classification criteria required for building limes differ from those for cements.

By the time British standards were developed for building limes, the use of hydraulic limes had ceased in mainstream building work and so BS 890 for building limes (BSI, 1995) only covered the various forms of air limes. Indeed, it was partly due to the lack of standards for hydraulic limes that their use was discouraged, as noted by Cowper (1927):

... lack of uniformity and absence heretofore of any exact standards of quality greatly handicap these natural lime products in competition with the artificial and closely controlled product. The 
latter is therefore likely to continue to be preferred for exacting work.

It was only in 1995 with the publication of a draft European standard (ENV 459: Part 1: Building lime: definitions, specifications and conformity criteria) that hydraulic limes came into the UK specification arena, becoming the full BS EN 459 standard in 2001 (BSI, 2001). Until these standards were introduced, purchasers of lime could only refer to the classification produced by Vicat (1837):

Rich limes are such as may have their volume doubled, or more, by slaking and whose consistency after many years of immersion remains nearly the same;

Feebly hydraulic limes set within fifteen or twenty days, after immersion in water of a container two-thirds full of lime, and continue to harden slowly to six or eight months;

Moderately hydraulic limes set within six to eight days and continue to harden even to the twelfth month; whilst Eminently hydraulic limes set from the second to the fourth day and, after one month, are already very hard.

Vicat also introduced a classification based on the clay content of the raw material: rich limes having less than $6 \%$ clay; feebly hydraulic limes having 6-12\% clay; moderately hydraulic limes having $12-18 \%$ clay; and eminently hydraulic limes having 18 $25 \%$ clay. There was also an intermediate class of 'poor' or 'semi-hydraulic' limes between the rich and feebly hydraulic. From Dibdin's reported analysis (Dibdin, 1911) it appears that Dorking greystone lime, at $6 \%$ clay, fell into this category.

Vicat also introduced a 'hydraulic index' based upon chemical analysis that compared the silica percentage plus the alumina percentage with the lime percentage. Relevant values were considered to be: rich limes less than $0 \cdot 1$; feebly hydraulic $0 \cdot 1-$ $0 \cdot 2$; 'good' hydraulic $0 \cdot 2-0 \cdot 4$. A further development was the 'cementation index' introduced by Eckel (1905), which was based on the potential hydraulic compounds and the proportion of the compounds combining with lime so that 2.8 times silica plus $1 \cdot 1$ times alumina plus $0 \cdot 7$ times the iron oxide were compared with the lime content. The problem with these ratios and indices is that they only indicate the potential hydraulicity and, as already noted, the final properties are determined by the quality of the burning process, hence the drawbacks reported by Cowper. These ratios and indices are therefore more relevant to the exploration for suitable raw materials than as a guide to the quality of the burnt lime.

These shortcomings were addressed for the so-called rich limes in BS 890 (BSI, 1995) in which the term 'air limes' was confirmed on account of their ability to harden in air by carbonation. They were categorised according to their calcium oxide content into CL90 ( $\geqslant 85 \%)$, CL80 ( $\geqslant 75 \%)$ and CL70 ( $\geqslant 65 \%)$, with limits on contents of magnesia, carbonate and sulfate and a test for soundness. This classification and the tests apply to all forms of calcium lime - whether quicklime, hydrated lime or lime putty and have carried through to the European standard (BSI, 2001). The air lime most often encountered in UK building work is CL90 hydrated calcium lime.

The introduction of the European standard brought a clearer specification for hydraulic limes. A strength test (BSI, 2005a) was introduced based on a convenient mortar formulation that would provide results at the reasonably quick age of 28 days. While the actual numbers are not directly relatable to everyday mortar strengths, they do provide a reproducible test and allow a system of classification based on the actual hydraulicity of the finished product. Natural hydraulic limes are now classified according to their minimum and maximum 28-day strength as NHL $2\left(2 \cdot 0-7 \cdot 0 \mathrm{~N} / \mathrm{mm}^{2}\right)$; NHL $3 \cdot 5\left(3 \cdot 5-10 \cdot 0 \mathrm{~N} / \mathrm{mm}^{2}\right)$ and NHL $5\left(5 \cdot 0-15 \cdot 0 \mathrm{~N} / \mathrm{mm}^{2}\right)$. At first glance this classification appears confusing as a strength of $5.0 \mathrm{~N} / \mathrm{mm}^{2}$ could qualify for all three classes. In fact, the classification is based on a statistical assessment requiring a safety margin at both upper and lower limits based on the variability of the producer. In practice, the compliance criteria become close to NHL $2(3 \cdot 5-$ $\left.6.0 \mathrm{~N} / \mathrm{mm}^{2}\right)$, NHL $3.5\left(6 \cdot 0-9 \cdot 0 \mathrm{~N} / \mathrm{mm}^{2}\right)$ and NHL $5(9 \cdot 0$ $12 \cdot 5 \mathrm{~N} / \mathrm{mm}^{2}$ ).

A quality control system was introduced with the European standard based on the level 2 procedure. While this was a step in the right direction, there were seen to be limitations in that level 2 only required certification that a producer had an initial system and relied on unaudited producer declarations thereafter. The current revision will change this to a level $2+$ system whereby the initial system is backed by annual third-party inspection.

A move by the UK to introduce a CEN classification of NHL 1 is ongoing but unlikely to be successful in the current revision as insufficient information on performance is available.

\section{Properties and applications}

The applications for building limes in modern building - which apply equally well to modern construction and conservation, and brick cavity and solid rubble stone walls - are numerous and well documented. The thorough discussion given by Blundell (2007) is summarised here.

The microstructure of hydrating lime systems becomes increasingly complex from air limes to eminently hydraulic limes. The first stage is the precipitation of calcium hydroxide as portlandite crystals. In the case of hydraulic limes, this is followed by the hydration of silicate phases to the 'glue' that holds the system together, calcium-silicate-hydrate (CSH). The greater proportion of portlandite and relatively smaller amount 
of CSH compared with a cement system produces the more open microstructure that gives the lower strengths, lower brittleness and greater permeability of lime systems. The presence of silicate as dicalcium silicate (belite) compared with the tricalcium silicate (alite) in Portland cement has a fundamental effect on properties. While both are unstable in the presence of water, decomposing and releasing heat, alite releases three times more heat than belite (Taylor, 1997). Belite thus reacts more slowly and is more affected by cooler conditions. In practical terms, this means that greater care has to be taken with hydrating lime: protecting for longer periods and avoiding low-temperature conditions (it is generally advised not to work with lime in temperatures below $5^{\circ} \mathrm{C}$ ).

Lime applied as mortar or render benefits from the superior permeable and flexible properties. The first thought in making a building resistant to water ingress is usually to apply a waterproof coating in the form of paint, cement render or some other coating product or system. However, the problem with these is that inevitably there will be some movement or deterioration that will result in cracks, allowing the ingress of water liquid or vapour. As the crack is a miniscule part of the structure, water is prevented from release by evaporation through the remaining impervious coating, causing the internal concentration to grow with subsequent onset of internal damp, rot and loss of the thermal insulation properties reducing building efficiency. Lime, however, allows a building to 'breathe'. In wet conditions, water is absorbed into the wall but, as soon as the rain stops, the movement is reversed, accelerated by wind, and the wall dries out, thus preventing dampness and rot. Similar advantages are to be found with regard to structural movement either from ground conditions or solar effects. The flexibility of a lime mortar reduces the risk of cracking and the ability of lime to heal cracks autogenously by precipitation of calcium carbonate helps to seal those cracks that do occur. Again, overall weathertightness is retained.

The permeability properties of lime assist in the prevention of frost damage to masonry units. Using a mortar that is less permeable than the masonry units causes moisture to be retained in the units themselves. The use of lime mortar, which is more permeable than the masonry, provides a breathing route for the masonry to dry out. In freezing conditions it is the wet part that freezes, with accompanying risk of frost damage. Lime-mortared masonry provides a uniform monolith that withstands weathering more effectively.

Figure 4 demonstrates the corrosive effect cement mortar can have on sandstone masonry: the stone is eroded while the dense mortar has remained unaffected. Figure 5 shows the use of lime mortar in a traditional role and Figure 6 shows a less familiar modern application in the recently completed awardwinning Joseph Chamberlain sixth form college.

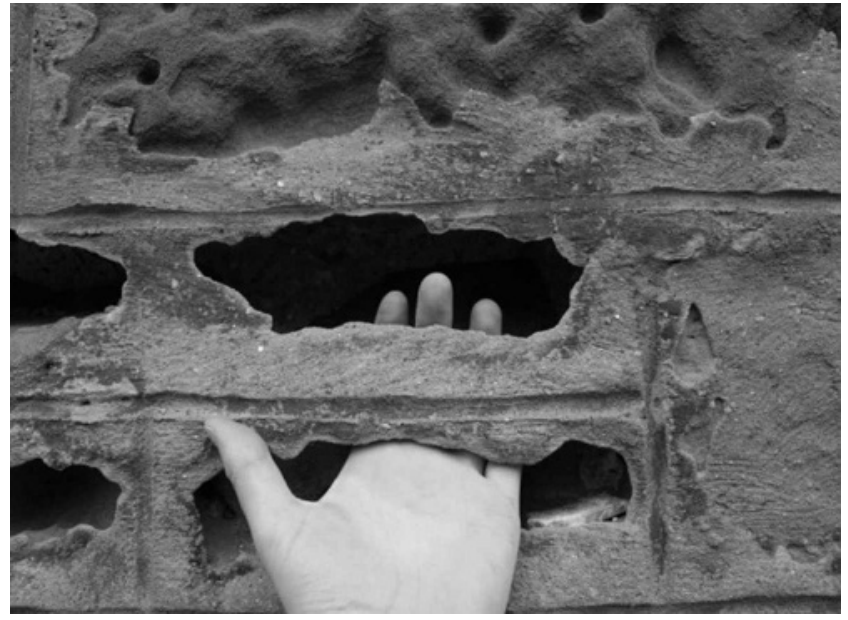

Figure 4. Eroded cement-mortared stone masonry (photograph permission of the Scottish Lime Centre Trust)

The major ingredient in a mortar is sand, and this component is even more important in a lime mortar. Lime is a finely dispersed powder of significantly lower density than sand, and therefore a special mix design procedure is required. In particular, with so much fine material present, a rather coarser sand is required than would be the case for a cement mortar. The most important investigation into the effects of mix design at the time when lime mortars predominated was that carried out by Dibdin (1911). His conclusion was that a hydraulic lime mortar produced the best results when clean, coarse, wellgraded sand was used. The term 'well-graded' is commonly used to mean sand for which the size fractions are approximately evenly distributed across several intermediate sizes.

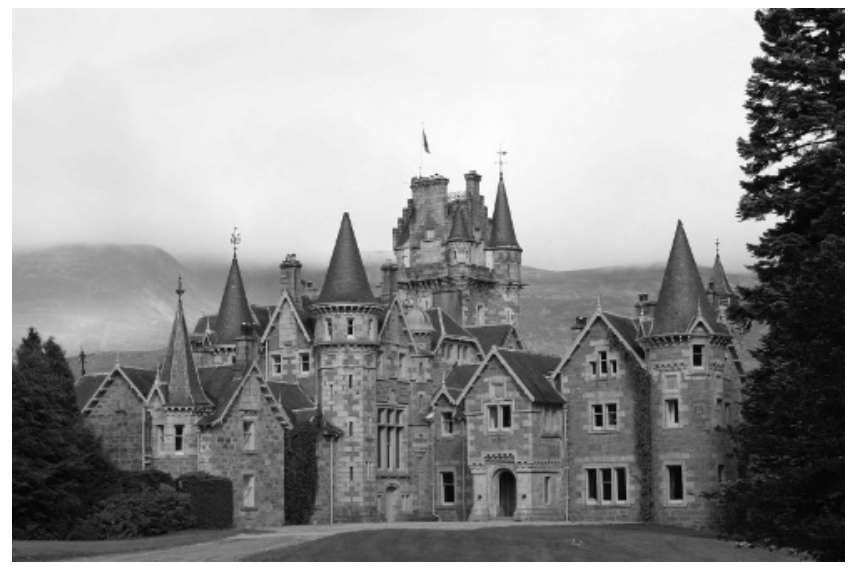

Figure 5. Example of traditional use of lime mortar: Ardverikie House, Scottish Highlands. The house was used as the setting for Glenbogle House in the Monarch of the Glen television series (photograph permission of the Scottish Lime Centre Trust) 


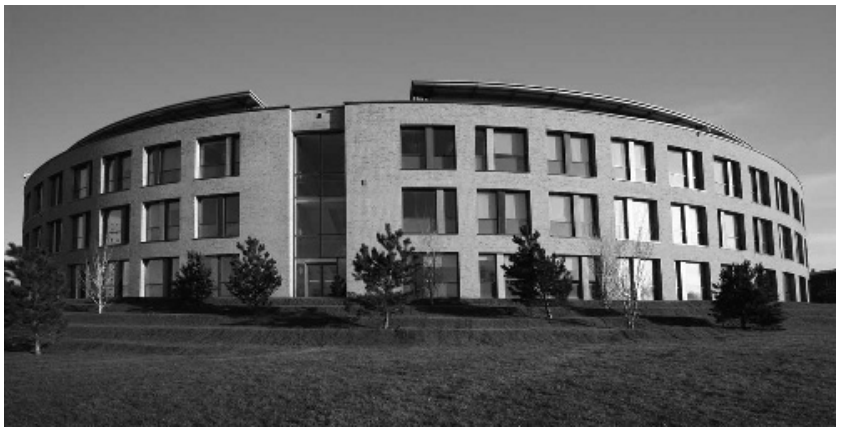

Figure 6. Royal Institute of British Architects award-winning Joseph Chamberlain college, Birmingham (photograph permission of Limetechnology Limited)

Table 1 compares the grading of Dibdin's choice Thames sand with that of more recent standards for sand, currently termed 'fine aggregate' and more suited to cement mortars. It can be seen that specifications have become less precise and drifted further from the 'ideal' over the past 100 years. In the UK, guidance (BSI, 2005c) on the most recent standard notes: 'For lime based mortars the requirements in this (BS EN 13139) specification should be reviewed using expert advice'. For this reason, the UK continues to retain BS 1199/1200 for specialist sand specification for lime mortars (BSI, 1976a).

The applications of lime mortars are numerous and are summarised in Table 2. This general guide is subject to consideration of the many variables and possible permutations, including location, microclimate and design lifetime. Table 3 gives a guide to the possible permutations of mix proportions and lime strength classes to produce mortars meeting the application durability classes. Again, variations due to individual limes and sands should be taken into account.

\section{Environmental factors}

Examination of the so-called carbon footprint of everything we do and use is becoming increasingly common. However, the methodology for determination of this footprint is indistinct and often relies on folklore or dubious data. The fact that lime is burnt at lower temperatures than required for cement leads to the assumption that lime must be more environmentally friendly, without consideration of all the factors involved. A variety of kilns are used to produce lime and their energy efficiency is equally variable. Wingate (1985) gives comparative data ranging from $2500 \mathrm{kcal} / \mathrm{kg}$ for a basic batch kiln to $750 \mathrm{kcal} / \mathrm{kg}$ for an exceptionally efficient shaft kiln. For major producers of hydraulic lime, a value of $800 \mathrm{kcal} / \mathrm{kg}$ is a reasonable estimate of performance (Livesey, 2007). This is comparable to a general cement kiln, which has the benefit of much higher throughput and hence economy of scale.

In calculating carbon footprint, it is necessary to convert the measure of efficiency to carbon dioxide emitted per kilogram of product. In the case of rich air limes, the calcium carbonate calcination requirement is much greater than that for hydraulic limes or cement. The emitted carbon dioxide for CL90 could be estimated as $0.88 \mathrm{~kg} \mathrm{CO}_{2} / \mathrm{kg}$ compared with around $0.77 \mathrm{~kg}$ $\mathrm{CO}_{2} / \mathrm{kg}$ for natural hydraulic lime and Portland cement.

The mortar design is a further factor, varying from 1:6 for a Portland cement (PC):sand aerated mortar to 1:2 for NHL 2:sand (1:3 for NHL 3·5:sand and 1:4 for NHL 5:sand). This results in carbon dioxide emissions of $175 \mathrm{t} / \mathrm{m}^{3}$ for PC:sand, $250 \mathrm{t} / \mathrm{m}^{3}$ for NHL 2:sand, $210 \mathrm{t} / \mathrm{m}^{3}$ for NHL $3 \cdot 5$ :sand and $170 \mathrm{t} / \mathrm{m}^{3}$ for NHL 5:sand.

Lime mortars will reabsorb carbon dioxide more quickly than do cement mortars. Some authorities have concluded that this varies depending on the wall design and thickness and the lime type. Thus, a CL90 mortar will carbonate rapidly while a

\begin{tabular}{lccccccc}
\hline & \multicolumn{7}{c}{ Size range: $\mathrm{mm}$} \\
\cline { 2 - 7 } & Above 5.0 & $2 \cdot 4-5 \cdot 0$ & $1 \cdot 2-2 \cdot 4$ & $0 \cdot 6-1 \cdot 2$ & $0 \cdot 3-0 \cdot 6$ & $0 \cdot 15-0 \cdot 3$ & $0 \cdot 15$ \\
\hline Thames sand (Dibdin, 1911) & $0 \cdot 8$ & $5 \cdot 2$ & $12 \cdot 6$ & $11 \cdot 8$ & $53 \cdot 2$ & $12 \cdot 8$ & $3 \cdot 6$ \\
BS 882: 1965 Zone 3 (BSI, 1965) & $5 \cdot 0$ & $2 \cdot 5$ & $10 \cdot 0$ & $12 \cdot 5$ & $44 \cdot 0$ & $21 \cdot 0$ & $5 \cdot 0$ \\
BS 1200: 1976 Type S (BSI, 1976a) & $1 \cdot 0$ & $4 \cdot 0$ & $10 \cdot 0$ & $15 \cdot 0$ & $34 \cdot 0$ & $30 \cdot 0$ & $5 \cdot 0$ \\
BS 882: 1976 Zone 3 (BSI, 1976b) & $5 \cdot 0$ & $2 \cdot 5$ & $5 \cdot 0$ & $18 \cdot 0$ & $43 \cdot 5$ & $21 \cdot 0$ & $5 \cdot 0$ \\
CEN reference sand (BSI, 2005a) & $0 \cdot 0$ & $0 \cdot 0$ & $7 \cdot 0$ & $26 \cdot 0$ & $34 \cdot 0$ & $20 \cdot 0$ & $13 \cdot 0$ \\
BS EN 13139: 2000 Class 0/4 MP & $2 \cdot 5$ & $5 \cdot 5$ & - & - & $30-70$ & \\
(BSI, 2000) & & & & & &
\end{tabular}

Table 1. Distribution of sand fractions across the size range (mean value \%w/w in each size) 
External walls including outer leaf of cavity walls in sheltered and moderate locations

Unrendered

Rendered

External walls as facing to solid construction

Work below or near to ground level

Below damp-proof course but no more than $150 \mathrm{~mm}$ above finished ground level

Below ground or above ground not within $150 \mathrm{~mm}$ of ground level

Sills and cornices

External free-standing walls excluding capping or coping

Parapets (excluding capping or coping)

Rendered

Unrendered

Copings, cappings and plinths

Retaining walls

Sewer-bed walls and other unlined walls intended for water retention externally

NHL 5 mortar is slower and Portland cement even slower still. Nevertheless, it is claimed (Lagarblad, 2005) that most mortars will reach a high degree of carbonation by the end of their working life. Hence it is problematic to claim any significant advantage from the embodied carbon in masonry mortar.

Lime mortars can, however, claim their largest environmental benefit from the fact that, in a wall, the highest embodied carbon is in the masonry unit. Because lime-mortared masonry has a lower bond strength between the mortar and the masonry units than cement-mortared masonry, it is easier to recover and reuse masonry units from a lime-mortared structure.

\section{Specification of lime mortars}

Tables 2 and 3 provide a guide to the selection of appropriate lime mortars. Current UK codes and specifications are based on Portland cement mortars. Reference to lime mortars barely survived the final revision of CP 121 (BSI, 1973) and totally disappeared with the publication of BS 5628 (BSI, 2005b). However, there is some progress being made following the publication of a draft for development of BS 5628: Part 4 (NHBC, 2008), which gives engineers a basis for evaluation and specification of lime mortars. This draft for development standard provides the specific technical data and guidance needed to enable the structural design of unreinforced brick

\begin{tabular}{|c|c|c|c|c|c|}
\hline $\begin{array}{l}\text { Hydraulic lime } \\
\text { mortar class }\end{array}$ & NHL 2:sand & NHL $3 \cdot 5$ :sand & NHL 5:sand & $\begin{array}{c}\text { Compressive strength at } \\
91 \text { days: } \mathrm{N} / \mathrm{mm}^{2}\end{array}$ & $\begin{array}{c}\text { Mortar durability } \\
\text { class }\end{array}$ \\
\hline HLM 5 & - & $1: 1$ & $1: 2$ & $5 \cdot 0$ & $9-10$ \\
\hline HLM $3 \cdot 5$ & - & $1: 1 \cdot 5$ & $1: 3$ & $3 \cdot 5$ & $7-8$ \\
\hline HLM $2 \cdot 5$ & - & $1: 2$ & $1: 4$ & $2 \cdot 5$ & $5-6$ \\
\hline HLM 1 & $1: 2$ & $1: 3$ & - & $1 \cdot 0$ & $3-4$ \\
\hline HLM 0.5 & $1: 3$ & $1: 4$ & - & 0.5 & $1-2$ \\
\hline
\end{tabular}

Table 3. Equivalent hydraulic lime mortar (HLM) mixes (Allen et al., 2003) (copyright Donhead Publishing Limited) 
masonry units used in combination with natural hydraulic lime-based mortars rather than cement-based mortars. In the drafting of this publication, it has been assumed that the design of masonry made with lime mortar is entrusted to chartered structural or civil engineers or other appropriately qualified persons, for whose guidance it has been prepared, and that the execution of the work is carried out under the direction of appropriately qualified supervisors.

Many aspects of the drafting of specifications, mix approval, workmanship on site, aftercare of work and health and safety precautions are fundamental. Details of many of these are to be found in the literature (Allen et al., 2003).

\section{Conclusions}

The advantages of lime mortars are being increasingly recognised, initially driven by the desire to reduce embodied carbon and enable masonry to be reused. The technological base for lime and its applications are developing from a century of techniques applied to cement mortar and (mainly) concrete, but are being delayed by a lack of research funding for what is seen as 'old technology'. The relevance of some taboos, such as the now lifted ban on 'gauged lime', has been clarified by relevant research, albeit remaining in the trade folklore. The opportunities to be presented by the new standard and the classes of hydraulic and pre-formulated limes are endless, and will lead to limes that have superior properties and are more user-friendly. Uptake by a conservative and sceptical market will inevitably be slow and will require strong advocates backed by sound science.

\section{REFERENCES}

Allen GC, Allen J, Elton N et al. (2003) Hydraulic Lime Mortars. Donhead, Shaftesbury.

Blundell C (2007) Precious Inheritance - The Conservation of Welsh Vernacular Buildings. Lime Company of West Wales, Crymych.

BSI (British Standards Institution) (1965) BS 882: Specification for aggregates for concrete. BSI, Milton Keynes.

BSI (1973) CP 121: Part 1: Code of practice for walling - brick and block masonry. BSI, Milton Keynes.

BSI (1976a) BS 1200: Sands for mortar. BSI, Milton Keynes.

BSI (1976b) BS 882: Specification for aggregates for concrete. BSI, Milton Keynes.

BSI (1995) BS 890: Building limes. BSI, Milton Keynes.

BSI (2000) BS EN 13139: Aggregates for mortar. BSI, Milton Keynes.

BSI (2001) BS EN 459: Part 1: Building limes. BSI, Milton Keynes.

BSI (2005a) BS EN 196: Part 1: Determination of strength. BSI, Milton Keynes.

BSI (2005b) BS 5628: Code of practice for the use of masonry. BSI, Milton Keynes.

BSI (2005c) PD 6678: Guide to the specification of masonry mortar. BSI, Milton Keynes.
CASS (Chinese Academy of Social Sciences) (2009) More light shed on China's ancient past. See www.cass.net.cn for further details (accessed 17/11/2009).

Cowper AD (1927) Lime and Lime Mortars. Donhead, Shaftsbury (Reprinted 1998).

Dibdin WJ (1911) The Composition and Strength of Mortars. Royal Institute of British Architects, London.

Eckel EC (1905) Cements, Limes and Plasters. Donhead, Shaftesbury.

Edwards DD (2009) Sustainable Lime Mortars. PhD thesis, Bristol University.

Holmes S (2006) To wake a gentle giant - grey chalk limes test the standard. Journal of the Building Limes Forum 13: 9-24.

Lagarblad B (2005) Carbon Dioxide Uptake During Concrete Life Cycle - State of the Art. Swedish Cement and Concrete Research Institute, Stockholm, CBI report 2.

Livesey P (2007) Reducing the carbon footprint of masonry mortar. Journal of the Building Limes Forum 14: 76-82.

NHBC (National House-Building Council) (2008) NF12, DD 5628, Part 4: The structural use of unreinforced masonry made with natural hydraulic lime mortars - technical annex for use with BS 5628-1: 2005: The use of lime-based mortars in new build. NHBC, Amersham.

Smeaton J (1791) Narrative of the Building, \&c, of the Eddystone Lighthouse. Smeaton, London.

Taylor HFW (1997) Cement Chemistry, 2nd edn. Thomas Telford, London.

Vicat LJ (1837) Mortars and Cements (Smith JT (transl.). Weale, London (reprinted 1997, Donhead, Shaftesbury).

Vitruvius (1880) Architecture, Books II and VII. Gwilt, London. Wingate M (1985) Small Scale Lime Burning. Intermediate Technology Publications, London.

\section{WHAT DO YOU THINK?}

To discuss this paper, please email up to 500 words to the editor at journals@ice.org.uk. Your contribution will be forwarded to the author(s) for a reply and, if considered appropriate by the editorial panel, will be published as discussion in a future issue of the journal.

Proceedings journals rely entirely on contributions sent in by civil engineering professionals, academics and students. Papers should be 2000-5000 words long (briefing papers should be 1000-2000 words long), with adequate illustrations and references. You can submit your paper online via www.icevirtuallibrary.com/content/journals, where you will also find detailed author guidelines. 